\title{
Evaluation of Antinociceptive and Anti-Inflammatory Effects of Synthetic $O$-Prenylated Phenolic Derivatives
}

\author{
Niraldo Paulino $^{1 *}$, Amarilis Scremin Paulino² ${ }^{2}$ Priscila Vautier ${ }^{1}$, Laura Pisco ${ }^{3}$, Carolina Passarelli ${ }^{3}$, \\ José Matheus de Freitas Costa ${ }^{3}$, Dirk Michalik ${ }^{4}$, Paulo Celso Pardi ${ }^{1}$, José Agustín Quincoces Suárez ${ }^{3^{*}}$ \\ ${ }^{1}$ Grupo de Pesquisa e Desenvolvimento de Biomedicamentos (BIOMED), Programa de Mestrado Profissional em Farmácia, \\ Universidade Bandeirante de São Paulo, São Paulo, Brasil; ${ }^{2}$ Programa de Pós-Graduação em Farmácia, Universidade Federal de \\ Santa Catarina, Florianópolis, Brasil; ${ }^{3}$ Laboratório de Síntese Orgânica, Universidade Bandeirante de São Paulo, São Paulo, Brasil; \\ ${ }^{4}$ Leibniz-Institut für Katalyse an der Universität Rostock, Rostock, Germany. \\ Email: *niraldop@yahoo.com.br, "quinco99@hotmail.com
}

Received March $7^{\text {th }}, 2012$; revised April 20 ${ }^{\text {th }}, 2012$; accepted May $24^{\text {th }}, 2012$

\begin{abstract}
This work describes the synthesis, antinociceptive and anti-inflammatory effect of $O$-prenyl derivatives: $O$-prenyl derivatives 2-(3-methylbut-2-enyloxy)acetophenone (L1) and 3-methoxy-4-(3-methylbut-2-enyloxy)benzaldehyde (V1). Treatment with L1- or V1-produced antinociceptive effect on classical pain models: acetic acid abdominal contortions and formalin test (first and second phases), and in hot plate or tale flick models in mice without changing the locomotors performance, and anti-oedematogenic or anti-inflammatory effect in vivo: carrageenan-induced paw oedema and peritonitis in mice. In addition, L1 and V1 derivatives reduced nitric oxide production on RAW 264.7 cells stimulated with lipopolysaccharide without changing the cell viability. Taken together, our results show for the first time that L1 and V1 can produce antinociception and modulate inflammatory response when administered in mice.
\end{abstract}

Keywords: Anti-Inflammatory; Antinociception; Synthesis; $O$-Prenyl Compounds

\section{Introduction}

Analgesic and non-steroidal anti-inflammatory drugs are the main pharmaceutical drugs used to treat pain and inflammation, and their therapeutic effects are related to several molecular mechanisms such as cyclooxygenase and lipoxygenase inhibition and nuclear factor-kappa B modulation $[1,2]$. These drugs are also known to produce various side effects [3]. Therefore, the discovery of new compounds with potent analgesic and anti-inflammatory effects but without side effects can greatly contribute to the treatment of pain and inflammation. Based on this premise, several new drugs have been synthesised.

An attempt to synthesise 2-(3-methylbut-2-enyloxy) acetophenone using a previously reported method [4] with $o$-hydroxyacetophenone and prenyl bromide in the presence of sodium hydride/dimethylsulfoxide (DMSO) at room temperature resulted in a poor yield $(25 \%)$. Quincoces Suárez et al. [5] reported that this $O$-prenyl derivative L1 showed non-selective antiproliferative activity against 4 human carcinoma cell lines.

In 2008, we developed a method for the synthesis of 3-methoxy-4-(3-methylbut-2-enyloxy)benzaldehyde (V1) that exhibited antitumoral properties [6].

${ }^{*}$ Corresponding authors.
Some $o$-prenylated compounds are natural products, such as Brazilian green propolis [7] and plants [8].

A novel natural product, caffeic acid dimethylallyl ester, was identified, from Populus nigra, along with further phenolics such as $p$-hydroxyacetophenone, dimethyl caffeic acid and vanillin. Cunha et al. [9] isolated 3-[4(3-methyl-but-2-enyloxy)phenyl]acrylic acid methyl ester from plants (Eriostemon australasius Pers. Subsp. banksii). This compound was found and identified in this australian plant, but its biological properties were not studied.

Appendino et al. [4] reported the structural elucidation of a new $O$-prenylated acetophenone, 2-(3-methylbut-2enyloxy)acetophenone, from the roots of a sample of Ferula communis L., collected in Sardinia. These compounds have been reported to have antinociceptive and anti-inflammatory effects [10]. Our group obtained $O$ prenylated derivatives (Quincoces Suárez et al. 2006) that showed non-selective antiproliferative activity against lung carcinoma (NCI 460), melanoma (UACC62), breast carcinoma (MCF-7), and ovarian cancer cell lines expressing multidrug resistant phenotype (NCI/ADR-RES).

The aim of the present work is to evaluate the antinociceptive and anti-inflammatory effects of the $O$-prenyl derivatives 2-(3-methylbut-2-enyloxy)acetophenone (L1) 
and 3-methoxy-4-(3-methylbut-2-enyloxy)benzaldehyde (V1), on pain and inflammation, on in vitro and in vivo models.

\section{Material and Methods}

\subsection{Chemistry}

Thin layer chromatography (TLC) was carried out on a silica gel $60 \mathrm{GF}_{254}$ with detection by UV light $(\lambda=254$ $\mathrm{nm}$ ) and/or by charring with iodine. IR spectra were recorded with a Nicolet 205 Fourier transform (FT)-IR spectrometer. NMR spectra of ${ }^{1} \mathrm{H}(250.13 \mathrm{MHz})$ and ${ }^{13} \mathrm{C}$ $(62.9 \mathrm{MHz})$ were recorded on an AC 250 Bruker spectrometer with deuterochloroform as the solvent. Chemical shifts were referred to solvent signals $\left(\delta_{(1 \mathrm{H})}=7.26\right.$; $\left.\delta_{(13 \mathrm{C})}=77.0\right)$. Elemental analyses were performed on a carbon, hydrogen, nitrogen, and sulphur (CHNS) Leco932 analyser.

The general procedure used for synthesis of the $O$ prenyl derivatives $\mathrm{L} 1$ and $\mathrm{V} 1$ is as follows: To a stirred solution of the phenolic compound $(2 \mathrm{mmol})$ in dry DMF $(10 \mathrm{~mL})$, anhydrous potassium carbonate $(828 \mathrm{mg}, 6$ $\mathrm{mmol}$ ) was added and the solution was stirred for $30 \mathrm{~min}$ at $40^{\circ} \mathrm{C}$ under argon atmosphere. Prenyl bromide (596 $\mathrm{mg}, 4 \mathrm{mmol}$ ) was added drop-wise and the resulting mixture was heated and stirred for $8 \mathrm{~h}$ under the same conditions. Then, the mixture was poured into cold water $(50 \mathrm{~mL})$ and extracted with chloroform. The combined organic layers were washed with diluted sodium hydrogen sulphate solution, then with water, afterwards dried with $\mathrm{Na}_{2} \mathrm{SO}_{4}$, and evaporated under reduced pressure. The residue was purified by column chromatography on silica gel 60 (63-200 mesh, Merck) and with the appropriate eluent, we obtained L1 [6].

V1; IR (KBr): $3075(=\mathrm{CH}) ; 2970\left(\mathrm{CH}_{3}\right) ; 2877\left(\mathrm{CH}_{2}\right)$; $1681(\mathrm{C}=\mathrm{O}) ; 1595(\mathrm{C}=\mathrm{C}) ; 1274(\mathrm{C}-\mathrm{O}) \mathrm{cm}^{-1} ;{ }^{1} \mathrm{H}$ NMR (250.13 MHz, $\left.\mathrm{CDCl}_{3}, \delta\right): 9.84$ (s, 1H, CHO); 7.43 (d, 1H, $\left.{ }^{3} J_{5,6}=8.0 \mathrm{~Hz},{ }^{4} J_{2,6}=1.9 \mathrm{~Hz}, \mathrm{H}-6\right) ; 7.40\left(\mathrm{~d}, 1 \mathrm{H},{ }^{4} J_{2,6}=1.9\right.$ $\mathrm{Hz}, \mathrm{H}-2) ; 6.97$ (d, $\left.1 \mathrm{H},{ }^{3} J_{5,6}=8.0 \mathrm{~Hz}, \mathrm{H}-5\right) ; 5.51(\mathrm{~m}, 1 \mathrm{H}$, $\left.\mathrm{H}-2^{\prime}\right) ; 4.67\left(\mathrm{~d}, 2 \mathrm{H}, 3^{3} J_{1^{\prime}, 2^{\prime}}=6.5 \mathrm{~Hz}, \mathrm{H}-1^{\prime}\right) ; 3.92(\mathrm{~s}, 3 \mathrm{H}$, $\mathrm{MeO}$ ); 1.78 (br s, 3H, $\mathrm{CH}_{3}$-prenyl); 1.75 (br s, 3H, $\mathrm{CH}_{3}$-prenyl). ${ }^{13} \mathrm{C}\left(62.9 \mathrm{MHz}, \mathrm{CDCl}_{3}\right): 190.9$ (CHO); 153.8 (C-4); 149.8 (C-3); 138.7 (C-3'); 129.9 (C-1); 126.7 (C-6); 118.8 (C-2'); 111.5 (C-2); 109.0 (C-5); 65.9 $\left(\mathrm{C}-1^{\prime}\right) ; 56.0(\mathrm{MeO}) ; 25.8 \quad\left(\mathrm{CH}_{3}\right.$-prenyl); $18.3 \quad\left(\mathrm{CH}_{3}-\right.$ prenyl). Anal. Calc. for $\mathrm{C}_{13} \mathrm{H}_{16} \mathrm{O}_{3}$ : C, 70.86; H, 7.34. Found: C, 70.82; H, 7.30.

\subsection{Biological Assays}

The synthesised compounds, namely, L1 and V1 were screened in the inflammatory and pain models in vivo, and in nitric oxide production on RAW 264.7 murine macrophage cell line in vitro.

\subsubsection{Pharmacological Procedures}

We used male mice $(18-35 \mathrm{~g})$, housed at $22^{\circ} \mathrm{C} \pm 2{ }^{\circ} \mathrm{C}$ under a $12 \mathrm{~h}$ light-dark cycle. The animals were acclimatised to the laboratory for at least $1 \mathrm{~h}$ before testing and were used once throughout the experiments, which were carried out in accordance with the current guidelines for the care of laboratory animals and the ethical guidelines for investigations of experimental pain in conscious animals, Ethical Committee UNISUL (017/2005) and in accordance with Zimmermann [11].

\subsubsection{Chemically-Induced Abdominal Constrictions in Mice}

We monitored abdominal constrictions to i.p. injection of acetic acid $(0.6 \%$ in phosphate buffered saline (PBS)). The procedure was similar to that previously described [12]. The animals were treated with the compounds L1 or $\mathrm{V} 1(0.1,1$, or $10 \mathrm{mg} / \mathrm{kg}$, i.p.) or indomethacin $(1 \mathrm{mg} / \mathrm{kg}$, i.p.) $30 \mathrm{~min}$ beforehand the injection of irritants. Control animals received a similar volume $(10 \mathrm{~mL} / \mathrm{kg})$ of the vehicle ( $1 \%$ ethanol solution prepared with PBS). After the challenge, pairs of mice were placed in separate boxes and the number of abdominal constrictions was cumulatively counted.

\subsubsection{Formalin-Induced Nociception in Mice}

The procedure used was similar to that previously described [13]. Animals were pre-treated intraperitoneally with the compounds L1 or V1 $(0.1,1$, or $10 \mathrm{mg} / \mathrm{kg}) 30$ min before inducing pain, or with morphine (positive control to the first phase, $26.6 \mu \mathrm{mol} / \mathrm{kg}$, s.c.) or indomethacin (positive control to the second phase, $1 \mathrm{mg} / \mathrm{kg}$, i.p). Negative control animals received only the phosphate-buffered solution. Animals were slightly anaesthetized with ether, except when used to analyse the first(early, 0 - $5 \mathrm{~min}$ ) and second- (late, 15 - $30 \mathrm{~min}$ ) phases of the formalin test; $20 \mu \mathrm{L}$ of $2.5 \%$ formalin solution ( $0.92 \%$ formaldehyde) made up in phosphate-buffered solution was injected under the paw surface of the right hind paw. The mice, both control and treated, were simultaneously observed from 0 to $30 \mathrm{~min}$ following the formalin injection. The time spent licking the injected paw was timed with a chronometer and was considered as indicative of pain.

At the end of experiments, to assess the possible antioedematogenic activity, the animals were sacrified by cervical dislocation and the paws were cut at the knee joint and weighed on an analytical balance.

\subsubsection{Hot-Plate Test in Mice}

The hot-plate test was used to measure response latencies according to the method described by [14]. Animals were placed into a glass cylinder of $24 \mathrm{~cm}$ diameter on the heated surface, and the time (s) between placement, 
shaking or licking of the paws, or jumping was recorded as the response latency. The animals were treated with the compounds $\mathrm{L} 1$ or $\mathrm{V} 1$ (1 or $10 \mathrm{mg} / \mathrm{kg}$, i.p.) or with morphine (positive control, $26.6 \mu \mathrm{mol} / \mathrm{kg}$, s.c.), $30 \mathrm{~min}$ before the experiments. Control animals received the same volume of the vehicle ( $1 \%$ ethanol solution prepared with phosphate-buffered solution, $10 \mathrm{~mL} / \mathrm{kg}$, i.p.).

\subsubsection{Tail-Flick Test in Mice}

A radiant heat tail-flick analgesiometer was used to measure the response latencies as described by [15]. The reaction time was recorded for the control mice or for animals pre-treated with the compounds L1 or V1 (1 or $10 \mathrm{mg} / \mathrm{kg}$ ) or morphine $(26.6 \mu \mathrm{mol} / \mathrm{kg}$, s.c.), $30 \mathrm{~min}$ before the experiments. The animals were selected $24 \mathrm{~h}$ prior to the test on the basis of their reactivity in the model. A latency period of $20 \mathrm{~s}$ was defined as completely analgesic.

\subsubsection{Rotarod Test in Mice}

The apparatus used was a Hugo Basile, model-DS 37. The bar rotated at a constant speed of $22 \mathrm{rpm}$. Animals were treated with the vehicle i.p. (5\% ethanol solution prepared with phosphate-buffered solution, $10 \mathrm{~mL} / \mathrm{kg}$ ) or with the compounds L1 or V1 (1 or $10 \mathrm{mg} / \mathrm{kg}$ ) $30 \mathrm{~min}$ beforehand. The time(s) during which the animals remained on the rotarod was counted with a chronometer. The cut-off time was considered as $60 \mathrm{~s}$.

\subsubsection{Carrageenan-induced Paw Oedema in Mice}

The animals were divided into 5 groups $(\mathrm{n}=5)$ that were subjected to treatment with indomethacin i.p. $(1 \mathrm{mg} / \mathrm{kg})$, saline $(\mathrm{NaCl} 0.9 \%)$, the compounds L1 or V1 (1 or 10 $\mathrm{mg} / \mathrm{kg}$ ), $30 \mathrm{~min}$ before inducing oedema by subplantar injection of carrageenan $(300 \mathrm{mg} / \mathrm{paw})$. The right paw was injected with an equal volume of saline and was monitored by a procedure similar to that described elsewhere [16]. The paw oedema was registered by means of a plethysmometer (Hugo Basile, Italy) and calculated by observing the difference between paws in the time slots of $15,30,60,120$, and $240 \mathrm{~min}$.

\subsubsection{Acute Carrageenan-Induced Inflammatory Reaction in the Peritoneal Cavity of Mice}

The groups of animals were treated i.p. with the compounds L1 or V1 $(0.1,1$, or $10 \mathrm{mg} / \mathrm{kg})$ or indomethacin $(1 \mathrm{mg} / \mathrm{kg}), 30$ minutes before inducing inflammation by means of carrageenan $(1 \mathrm{mg} / \mathrm{mL}$, i.p.). $4 \mathrm{~h}$, the peritoneal fluid was collected in sterile and heparinised PBS $(1 \mathrm{~mL})$, and the total cells, differential cells, and the myeloperoxidase (MPO) assay were evaluated. Cell migration was quantified according to the method described by [17].

\subsubsection{Measurement of Myeloperoxidase Activity}

MPO is an enzyme essential for oxygen-dependent antibacterial activity in neutrophils. Since $5 \%$ of the polymorphonuclear mass is represented to MPO, the amount of exudate MPO can be used to indicate the cumulative migration of polymorphonuclear masses to tissues. The MPO activity was measured by the $\mathrm{H}_{2} \mathrm{O}_{2}$-dependent oxidation of tetramethylbenzidine (TMB). In a 96-well plate, $25 \mathrm{~mL}$ of peritoneal exudate sample, $25 \mathrm{~mL}$ of TMB solution (1.6 mM), and $100 \mathrm{~mL}$ of $\mathrm{H}_{2} \mathrm{O}_{2}(0.3 \mathrm{mM})$ (all from Sigma-Aldrich, São Paulo, Brazil) were placed, and the optical density (OD) was monitored at $450 \mathrm{~nm}$ in an enzyme-linked immune sorbent assay (ELISA) reader. The MPO activity was found to be proportional to the OD of the solutions in comparison with the activity of standard MPO solution. The animals were treated with the compounds $\mathrm{L} 1$ or $\mathrm{V} 1(0.1,1$, or $10 \mathrm{mg} / \mathrm{kg}$, i.p.) or indomethacin $(1 \mathrm{mg} / \mathrm{kg}$, i.p.), 30 minutes before inducing inflammation by means of carrageenan $(1 \mathrm{mg} / \mathrm{mL}$, i.p.). 4 $\mathrm{h}$, the peritoneal fluid was collected in sterile and heparinised PBS $(1 \mathrm{~mL})$ and used in the determination of MPO activity.

\subsubsection{Cell Culture}

RAW 264.7 cells obtained from the American Type Culture Collection (ATCC; Maryland, USA) were cultured in Dulbecco's modified essential medium (DMEM) with $4 \mathrm{mM}$ l-glutamine and $4.5 \mathrm{~g} / \mathrm{L}$ glucose (Biobras, Campinas, SP, Brazil) supplemented with $10 \%$ heat-inactivated foetal calf serum (Gibco/BRL Life Technologies, Eggenstein, Germany). The cells were maintained at $37^{\circ} \mathrm{C}, 5 \% \mathrm{CO}_{2}$, and used for experiments between passage 5 and 15 . Confluent cells were stimulated with 1 $\mu \mathrm{g} / \mathrm{mL}$ lipopolysacharidide (LPS) (Escherichia coli, serotype O55:B5; Sigma, Deisenhofen, Germany). The compounds L1 or V1 were freshly dissolved in an appropriate during the experiments and added to the cell culture medium. The solvent addition did not change the properties of the culture medium.

\subsubsection{Nitrite Assay (Griess Reaction)}

RAW 264.7 were seeded in a 96-well plate and cultured for 2 days, and then incubated with or without LPS in the absence or presence of the compounds L1 or V1 $(5,15$, or $50 \mu \mathrm{M}$ ) for $24 \mathrm{~h}$. As a parameter of analysing the NO synthesis, nitrite concentration was assessed in the supernatant of RAW 264.7 macrophages by Griess reaction. Briefly, $100 \mathrm{~mL}$ of the cell culture supernatant was removed and combined with $50 \mathrm{~mL} 1 \%$ sulfanylamide in $5 \% \mathrm{H}_{3} \mathrm{PO}_{4}$ and $50 \mathrm{~mL} 0.1 \% \mathrm{~N}$-(1-naphthyl)ethylenediamine dihydrochloride in water (all from Sigma-Aldrich) in a 96-well plate, followed by spectrophotometric measurement at $550 \mathrm{~nm}$ by using a microplate reader. Nitrite concentration in the supernatant was determined by 
comparing with a sodium nitrite standard curve. All experiments were performed at least 3 times and in triplicate.

\subsubsection{Cell Viability (MTT Assay)}

Cell respiration, an indicator of cell viability, was determined by mitochondrial-dependent reduction of 3-(4,5dimethylthiazol-2-yl)-2,5-diphenyl tetrazolium bromide (MTT; Sigma-Aldrich) to formazan [18]. After removal of the supernatant for nitrite determination, the cells were incubated at $37^{\circ} \mathrm{C}$ with MTT $(0.5 \mathrm{mg} / \mathrm{mL})$ for $45 \mathrm{~min}$ utes. The medium was aspirated and the cells were solubilised in DMSO $(250 \mathrm{~mL})$ for $3 \mathrm{~h}$ in the dark. The extent of reduction of MTT was quantified by OD measurement $(550 \mathrm{~nm})$.

\subsection{Statistical Analysis}

Results are expressed as mean values \pm standard error of the mean (SEM), except the median infective dose $\left(\mathrm{ID}_{50}\right)$ values (i.e. the doses of extract necessary to reduce the response by $50 \%$ relative to the control value), which are reported as geometric means accompanied by their respective $95 \%$ confidence limits. The statistical signifycance of the differences between the groups was obtained by means of analysis of variance (ANOVA) followed by Dunnett's multiple comparison test or by Student's t-test. $P$ values $<0.05$ were considered indicative of signifycance. When appropriate, the $\mathrm{ID}_{50}$ or median effective dose $\left(\mathrm{ED}_{50}\right)$ values were estimated from individual experiments by using least squares method.

Nitrite determination and cell viability experiments were performed in triplicate. All experiments were repeated at least twice. The results are expressed as mean values \pm SEM. Statistical comparisons were made by ANOVA followed by Dunnett's multiple comparison test. $P<0.005$ was considered significant by means of GraphPad Prism InStat Program (San Diego, CA, USA).

\subsection{Drugs}

Indomethacin, saline $(\mathrm{NaCl} 0.9 \%)$, acetic acid $(0.6 \%)$, formalin $(0.92 \%$ formaldehyde $)$, carrageenan, TMB solution (1.6 mM), $\mathrm{H}_{2} \mathrm{O}_{2}(0.3 \mathrm{mM})$, LPS $(1 \mu \mathrm{g} / \mathrm{mL})($ E. coli, serotype $\mathrm{O} 55: \mathrm{B} 5)$, sulfanylamide in $5 \% \mathrm{H}_{3} \mathrm{PO}_{4}, \mathrm{~N}-(1-$ naphthyl)ethylenediamine dihydrochloride, 3-(4,5-dimethylthiazol-2-yl)-2,5-diphenyl tetrazolium bromide, DMSO (all purchased from Sigma-Aldrich), DMEM with $4 \mathrm{mM}$ l-glutamine and $4.5 \mathrm{~g} / \mathrm{L}$ glucose (Biobras, Campinas, SP, Brazil), supplemented with $10 \%$ heatinactivated fetal calf serum (Gibco/BRL Life Technologies, Eggenstein, Germany).

Compound L1, 2-(3-methylbut-2-enyloxy)-acetophenone was synthesised from $o$-hydroxyacetophenone, prenyl bromide, and anhydrous potassium carbonate as the base in a 1:2:3 molar ratio in dry $N, N$-dimethylformamide (DMF), at $40^{\circ} \mathrm{C}$. After 8 hours the prenylether could be isolated with an excellent yield (85\%). Compound V1, 3-methoxy-4-(3-methylbut-2-enyloxy)benzaldehyde, was obtained 6 in 95\% yield as a white solid starting with vanillin and prenyl bromide and by using the same procedure described for L1 (Section 2.1).

\section{Results}

In the first step of the present work we have shown the synthesis of $O$-prenyl derivatives 2-(3-methylbut-2-enyloxy)acetophenone (L1) and 3-methoxy-4-(3-methylbut2-enyloxy)benzaldehyde (V1). Compound L1 was obtained and characterised as described earlier by our group [5]. The chemical structure of V1 was determined by spectroscopic methods and elemental analysis. The aldehyde group was found in the infrared (IR) spectra at $1681 \mathrm{~cm}^{-1}$. In the nuclear magnetic resonance (NMR) spectra of ${ }^{13} \mathrm{C}$ and ${ }^{1} \mathrm{H}$ of this compound, the signals for the formyl group were found at $\delta=190.9$ and $\delta=9.80$, respectively. The aromatic and prenyl protons appeared in their expected regions, thus excluding any other alternative structure (Figure 1).

We have demonstrated the effects of the administration of saline, indomethacin $(1 \mathrm{mg} / \mathrm{kg})$, or $\mathrm{L} 1$ or $\mathrm{V} 1$ in the respective administration $(0.1,1$, or $10 \mathrm{mg} / \mathrm{kg}$, i.p.) in an acetic acid-induced pain model. The data presented in this study show that systemic administration (i.p.) of L1 and V1 at doses that did not produce motor dysfunction or any detectable side effect produced marked and dose-related antinociception when assessed in chemical, but not in thermal assays of nociception. On an acetic

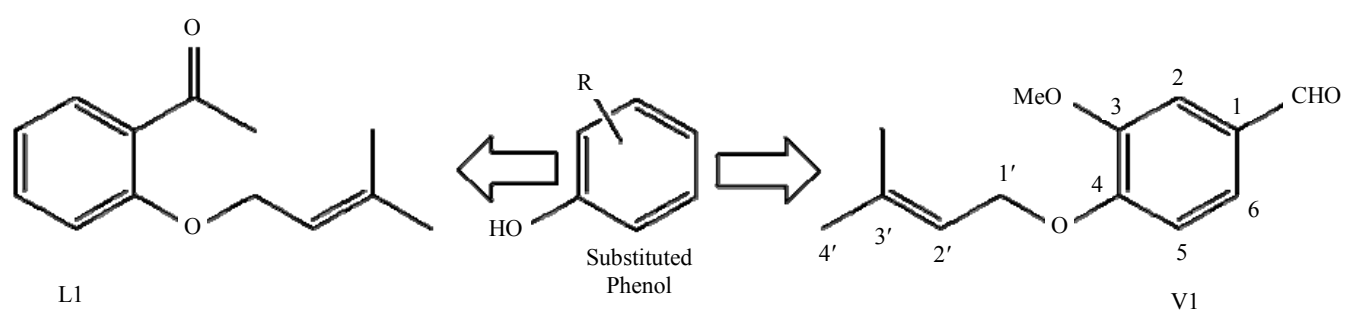

Figure 1. Synthesis of $O$-prenyl derivatives 2-(3-methylbut-2-enyloxy)acetophenone (L1) and 3-methoxy-4-(3-methylbut-2enyloxy)benzaldehyde (V1). 
acid-induced abdominal contortion model, L1 and V1 produced an antinociceptive effect and the half maximal inhibitory concentration $\left(\mathrm{IC}_{50}\right)$ values were $4.7 \pm 0.3$ and $0.7 \pm 0.1 \mathrm{mg} / \mathrm{kg}$, respectively (Figure 2). When compared with reference analgesic drugs, L1 was 10-fold less potent and V1 was equipotent with indomethacin. We have shown in our experiments the conclusive evidence to antinociceptive effect of $\mathrm{L} 1$ and $\mathrm{V} 1$. $O$-prenyl derivatives administered i.p. significantly inhibited the nociception when assessed in the formalin test. We have investigate the effects of the administration of saline, morphine $(26.6 \mu \mathrm{mol} / \mathrm{kg}$, s.c. $)$, indomethacin $(1 \mathrm{mg} / \mathrm{kg})$, or L1 (1 and 2), or V1 (3 and 4) (0.1, 1, or $10 \mathrm{mg} / \mathrm{kg}$, i.p.) in formalin-induced nociception assay (first and second phase). First phase of nociception elicited by formalin has an involvement of neuronal stimulation highly sensitive to morphine and related opioids. In spite of this evidence suggesting the involvement of opioid-like peptides in nociception we have shown that V1 produced maximal inhibition of $40 \% \pm 2 \%$ (Figure 3(c)), while L1 did not have such an effect during pharmacological phase of formalin-induced pain (Figure 3(a)). However, in the second phase (inflammatory phase) of formalin test, maximal antinociception produced by $\mathrm{L} 1$ was $91 \% \pm 3 \%$ and $\mathrm{IC}_{50}$ was $3.5 \pm 0.8 \mathrm{mg} / \mathrm{kg}$ (Figure 3(b)) and was more potent than indomethacin in this phase of formalin-induced pain. However, V1 did not have an effect in this second phase of formalin-induced pain (Figure 3(d)). Finally, we used the rotarod test to investigate the influence of the analgesic effects of L1 and V1 on the central nervous system, depressive activity, and muscular impairment, respectively; it was found that any dose of L1 and $\mathrm{V} 1$ produced modifications in the ability of the mice to stay on the bar in the test (results not shown).

We investigated the antinociceptive effect of the aforementioned $O$-prenyl compounds when assessed in

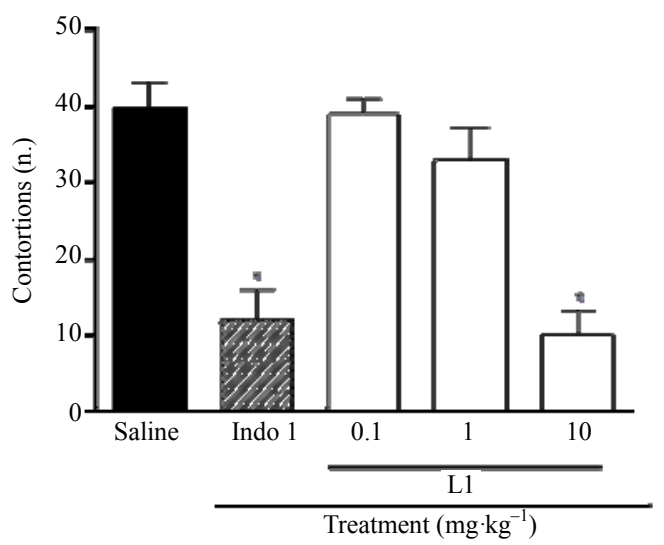

an acute thermal pain model and hot-plate test. We have shown the effects of the administration of saline, morphine $(26.6 \mu \mathrm{mol} / \mathrm{kg}$, s.c.), indomethacin $(1 \mathrm{mg} / \mathrm{kg})$, or $\mathrm{L} 1$, or V1 $(0.1,1$, or $10 \mathrm{mg} / \mathrm{kg}$, i.p.) on the hot plate and tail flick in mice. The treatment of both L1 and V1 did not present any effects in the concentrations used for the experiments (Figures 4(a), 4(b)). No evidence of crosstolerance with morphine was found when it was administered to mice that had received an s.c. injection of this opioid once a day for 7 consecutive days (results not shown). Thus, results of the present study support, at least in part, the role played by the inflammatory mediator system in the antinociceptive effect of L1 and nociceptive neuronal modulation (but not thermal) of V1.

The present study also analysed the possible role of L1 and V1 in carrageenan-induced paw oedema. Thus, results of the present study support, at least in part, the role played by the inflammatory mediator system in the antinociceptive effect of L1 and nociceptive neuronal modulation (but not thermal) of V1.

Our results demonstrated that $\mathrm{L} 1$, but not V1, was able to inhibit carrageenan-induced paw oedema in mice; this could possibly be linked to inhibition of inflammatory mediators (Figure 5).

Another interesting aspect investigated in the present study was the possible inhibitory effect of L1 and V1 in carrageenan-induced acute systemic peritoneal inflamemation in mice. In these experiments we have evaluated the effects of the administration of saline, indomethacin (1 mg/kg, i.p.), or L1 (1), or V1 (2) (1 or $10 \mathrm{mg} / \mathrm{kg}$, i.p.) in acute carrageenan-induced inflammatory reaction measured by the concentration of cells in the peritoneal fluid.

We have investigated the effects of treatment with saline, or L1 (1), or V1 (2) (1 or $10 \mathrm{mg} / \mathrm{kg}$, i.p.) on nitric oxide by RAW 264.7 cells stimulated with $1 \mu \mathrm{g} / \mathrm{mL}$

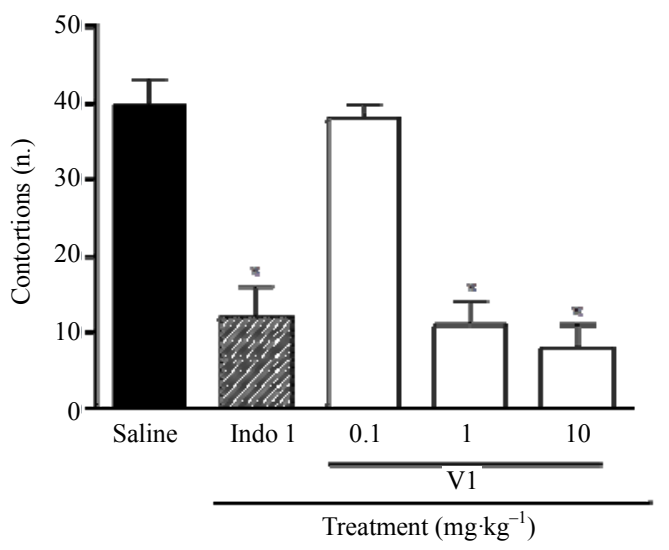

Figure 2. Effects of the administration of saline, indomethacin (Indo $1 \mathrm{mg} / \mathrm{kg})$, or L1 (1) or V1 (2) (0.1, 1, or $10 \mathrm{mg} / \mathrm{kg}$, i.p.) in an acetic acid-induced pain model. Each value represents the mean \pm standard error of mean (SEM) of 6 animals, and the asterisks indicate the significant inhibition in the number of abdominal constrictions in relation to the untreated groups, $P<$ 0.05 . 


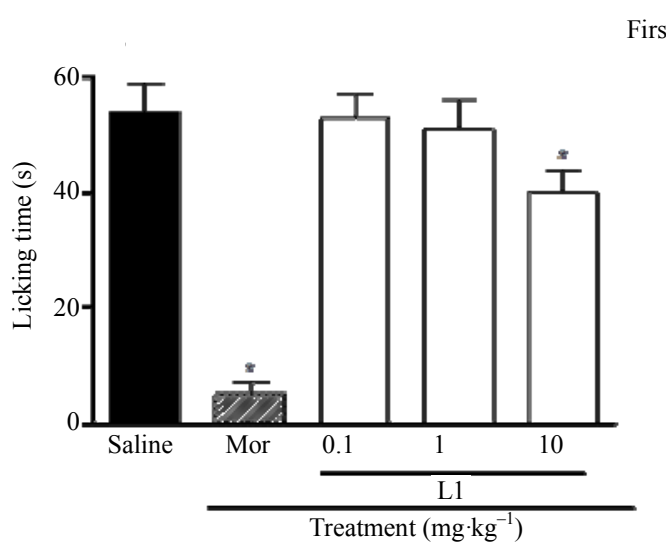

(a)

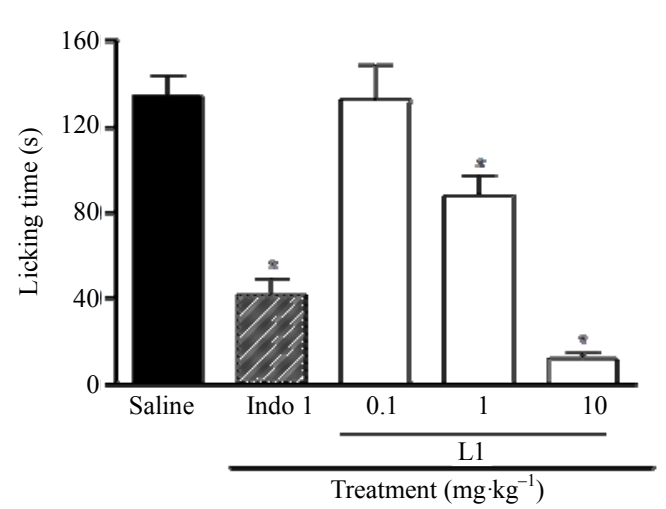

(b)

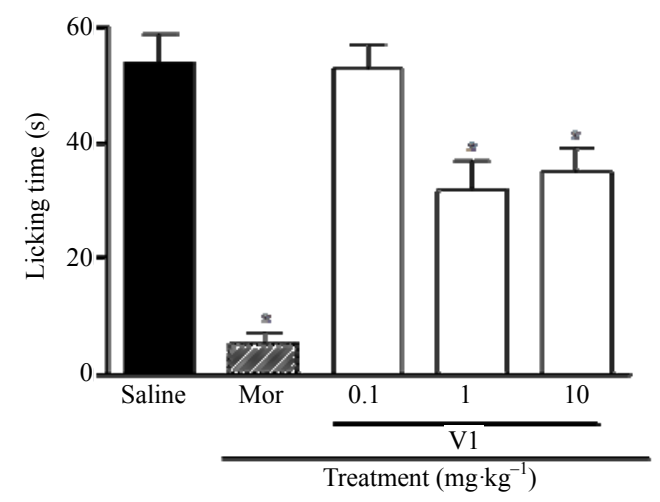

(c)

Second phase

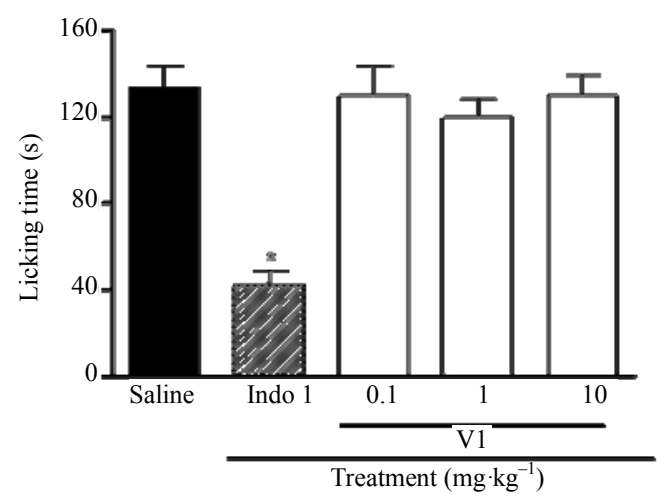

(d)

Figure 3. Effects of the administration of saline, morphine (26.6 $\mu \mathrm{mol} / \mathrm{kg}$, s.c.), indomethacin (Indo $1 \mathrm{mg} / \mathrm{kg})$, or $\mathrm{L1}$ (1 and 2$)$, or V1 (3 and 4) $(0.1,1$, or $10 \mathrm{mg} / \mathrm{kg}$, i.p.) in formalin-induced nociception assay (first and second phase). Each value represents the mean \pm SEM of 6 animals, and the asterisks indicate significant inhibition of the licking time to the untreated groups, $P<0.05$.

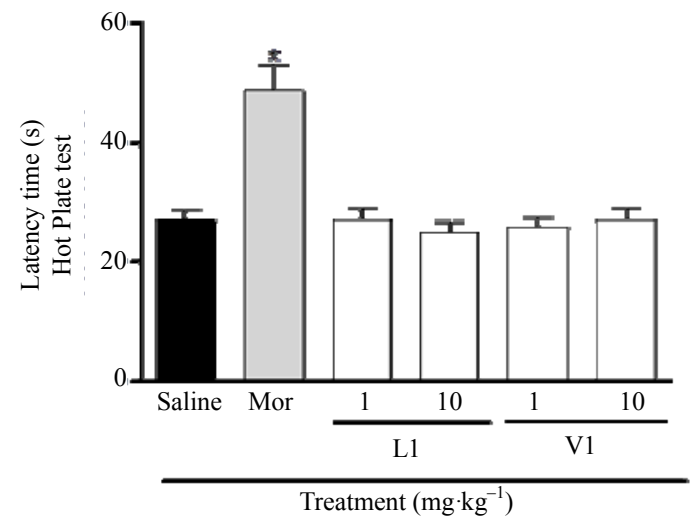

(a)

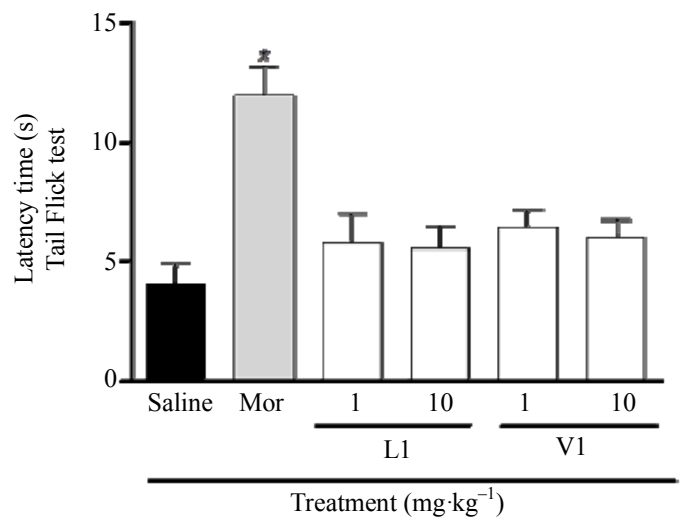

(b)

Figure 4. Effects of the administration of saline, morphine (26.6 $\mu \mathrm{mol} / \mathrm{kg}$, s.c.), indomethacin (Indo $1 \mathrm{mg} / \mathrm{kg})$, or L1, or V1 (0.1, 1 , or $10 \mathrm{mg} / \mathrm{kg}$, i.p.) on the hot plate (1) and tail flick (2) in mice. Each value represents the mean \pm SEM of 6 animals, and the asterisks indicate the significant inhibition of the licking time to the untreated groups, $P<0.05$.

lipopolysaccharide (LPS) for $24 \mathrm{~h}$, or cell viability after treatment with L1 or V1. As shown in Figure G, the L1 and $\mathrm{V} 1(50 \mu \mathrm{M})$ produced maximal inhibition of $20 \pm 2 \%$ and $40 \% \pm 3 \%$, respectively on nitric oxide production when RAW 264.7 cells were incubated with lipopolysaccharide (LPS) for $24 \mathrm{~h}$ (Figure 6). 


\section{Discussion}

In the present work we have demonstrated, on the first time, that the administration of $O$-prenylated compounds, $\mathrm{L} 1$ and V1 produced a potent antinociceptive and antiinflammatory effect in mice. We employed three standard tests to evaluate potential analgesic effects of L1 and V1. Acetic acid-induced writhing is useful for evaluation of nonsteroidal, anti-inflammatory compounds and widely used for detecting both central and peripheral analgesia Prostaglandin biosynthesis plays an important role in nociception under this model. In the present work, L1 and V1 produced significant analgesic effect, thus suggesting a peripheral mechanism. In addition to prostaglandins, several other inflammatory mediators, including interleukin-1 $\beta$ (IL-1 $\beta$ ), interleukin-8 (IL-8), tumour necrosis factor- $\alpha$ (TNF $\alpha$ ) and sympathomimetic amines, have been reported to be associated with the nociceptive response to acetic acid in mice [19]. Ribeiro et al. [20] showed that contortion-induced by acetic acid is highly dependent on both peritoneal macrophages and mast cells. This is an important data to future studies because the incubation of L1 and V1 reduced the nitric oxide production in macrophage cell line RAW 264.7. Then, we need to clarify the potential contribution of these additional mechanisms to the action of L1 and V1 in the acetic acid model.

In the formalin test, the induced pain in a biphasic manner. The first transient phase is produced by direct stimulation on sensory $\mathrm{C}$ fibers, whereas the second phase is caused mainly by inflammation. Drugs that act primarily in the central nervous system like central analgesics could inhibit both phases while drugs that acting peripherally can inhibit only the second phase. Substance $\mathrm{P}$ and bradykinin participate in the first phase, whereas histamine, serotonin, prostaglandin and bradykinin are involved in the second-phase responses elicited by for-

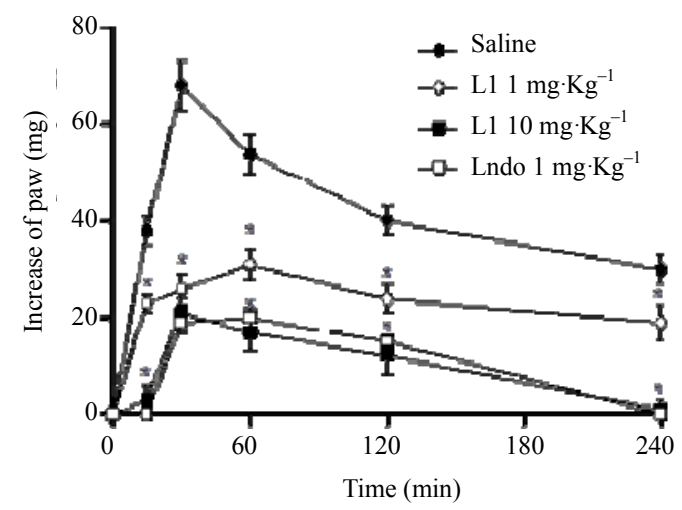

(a) malin. We have shown that L1 and V1 produced a significant, but not potent, effect in the first phase on formalin test, but only L1 was able to reduce the pain produced in the second phase, indicated that the action of L1 is mediated mainly through a peripheral mechanism with a weak central mechanism, whereas the antinoceptive action of V1 is mediated mainly through a central mechanisms.

Paw oedema induced by carrageenan is widely used as an inflammatory model with three different steps [21]. Several inflammatory mediators act in cascade to produce the inflammation. The initial step $(0-1 \mathrm{~h})$ is characterized by a release of histamine and serotonin. Bradykinin will be released in the second phase ( 2 to $4 \mathrm{~h}$ ). Finally, the last phase (4 to $6 \mathrm{~h}$ ) is correlated with an increase of prostaglandin levels produced by COX-2 activity, mainly [22].

We have shown that treatment with L1, but not V1, produces a strong anti-oedematogenic effect similar to indomethacin. These oedema-models are very sensitive to the kinins and prostanoid-systems, suggesting a possible interaction of this compound with these systems, and supporting that anti-oedematogenic effect is in agreement with pain-model results. This is a current in the literature that bradykinins and related kinins represent a group of potent inflammatory mediator peptides involved in pain and inflammation [23]. Bradykinin receptor B1 are associated with a metabotropic signalling producing vasodilatation, an increase of vascular permeability, and an increase of eicosanoids production, such as $\mathrm{PGE}_{2}$, and nitric oxide [24]. On the other hand, B1 receptors promote pain stimulus and inflammation by NF $\kappa$ B-pathway [25].

Our results showed that $\mathrm{L} 1$, but not V1, produced an important anti-oedematogenic effect in paw oedema induced by carrageenan, mainly ( 0 to $1 \mathrm{~h}$ ), time characterized by a release of histamine and serotonin and between

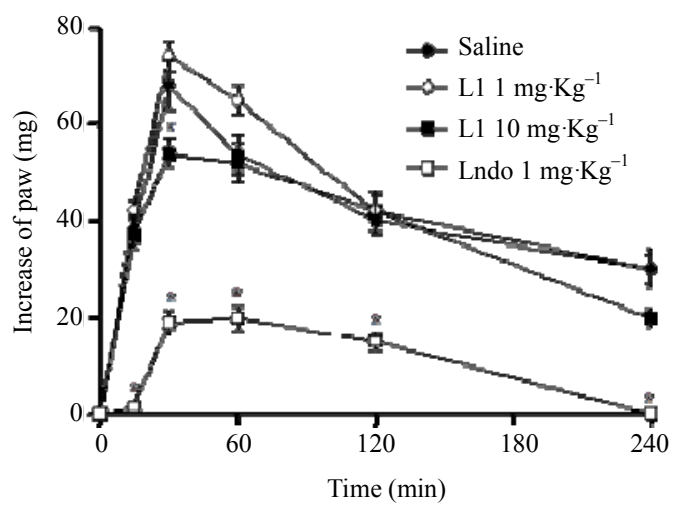

(b)

Figure 5. Effect of the administration of saline, indomethacin (Indo, $1 \mathrm{mg} / \mathrm{kg}$, i.p.), or L1 (1), or V1 (2) (1 or $10 \mathrm{mg} / \mathrm{kg}$, i.p.) in carrageenan-induced paw oedema in mice. Each value represents the mean \pm SEM of 6 animals, and the asterisks indicate the significant inhibition of total number of cells migrated in the peritoneal cavity in relation to the untreated groups, $P<0.05$. 


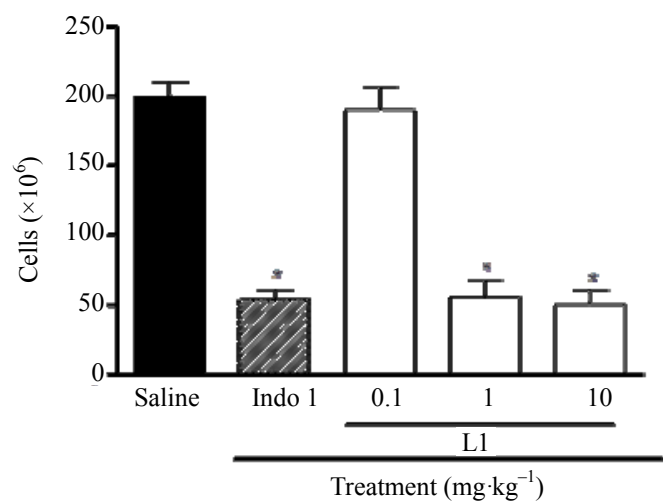

(a)

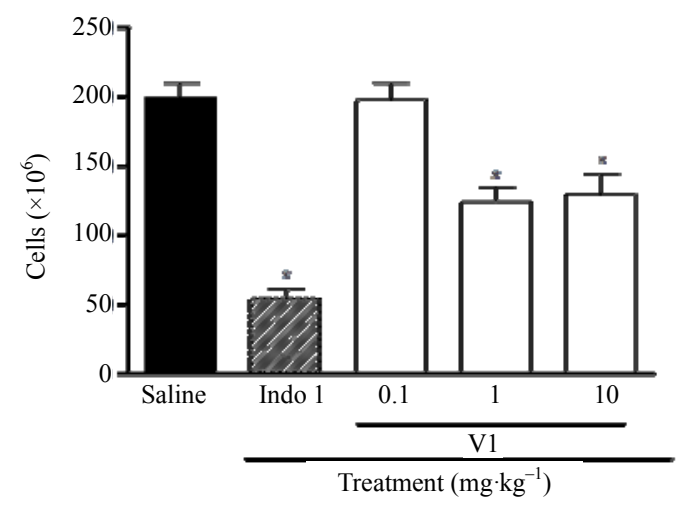

(b)

Figure 6. Effects of the administration of saline, indomethacin (Indo, $1 \mathrm{mg} / \mathrm{kg}$, i.p.), or L1 (1), or V1 (2) (1 or $10 \mathrm{mg} / \mathrm{kg}$, i.p.) in acute carrageenan-induced inflammatory reaction measured by the concentration of cells in the peritoneal fluid. Each value represents the mean \pm SEM of 6 animals, and the asterisks indicate significant inhibition of the total number of cells in the peritoneal cavity in relation to the untreated groups, $P<0.05$.

(a)

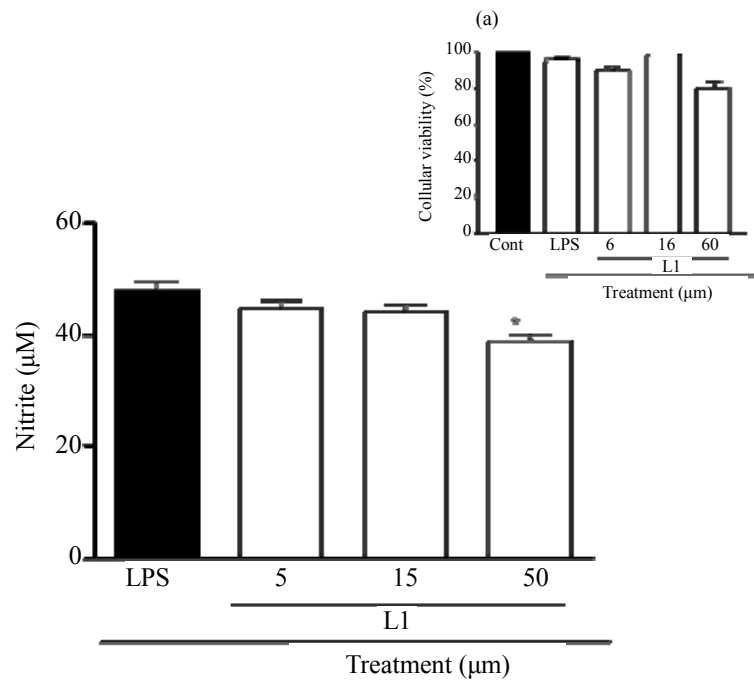

(A)

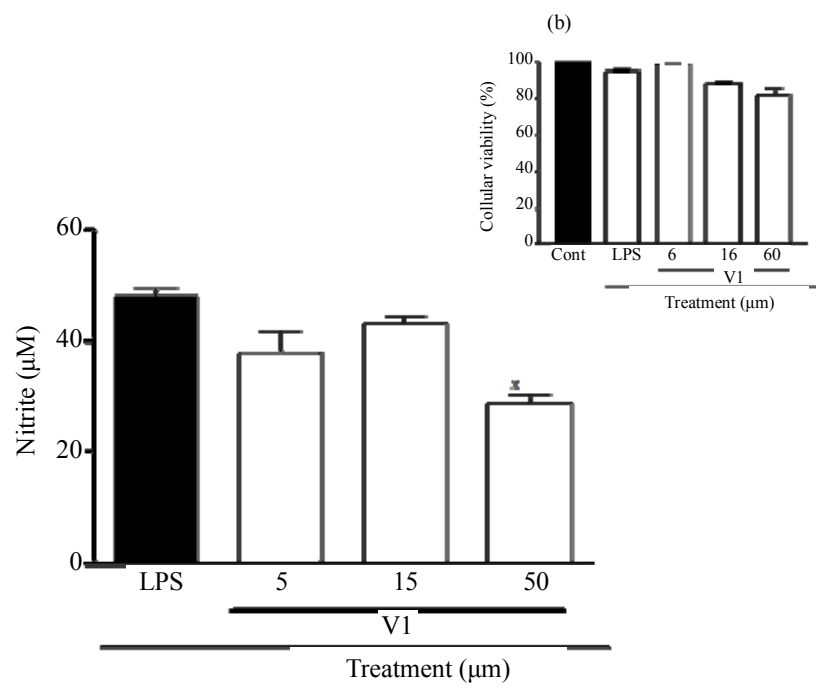

(B)

Figure 7. Effects of treatment with saline, or L1 (1), or V1 (2) (1 or $10 \mathrm{mg} / \mathrm{kg}$, i.p.) on nitric oxide by RAW 264.7 cells stimulated with $1 \mu \mathrm{g} / \mathrm{mL}$ lipopolysaccharide (LPS) for $24 \mathrm{~h}$, or cell viability after treatment with L1 (a) or V1 (b). Bars represent the mean \pm SEM of 3 independent experiments performed in triplicate, and the asterisks indicate significant inhibition of the enzyme activity in relation to the untreated groups, $P<0.05$.

( 2 to $4 \mathrm{~h}$ ), time where bradykinin will be released in the second phase ( 2 to $4 \mathrm{~h}$ ). This suggests that the anti-inflammatory effect of L1 can, at least in part, involve the kinin-system.

We demonstrated also that L1 and V1 produced a significant effect on cell migration during the carrageenaninflammation in the peritoneum cavity in mice, reduced the total cellular count in the peritoneal exudates. The preferential cell population present in the peritoneal exudates were neutrophils, shown by mean myeloperoxidase activity assay.

Inflammation is an important physiologic response that protects the organism during tissue injury induced by several etiologic agents. It is started with the chemical release of inflammatory mediators on injured tissue from migratory cells. This reaction is linked to pain or hyperalgesic sensitization. Our results have shown that the pretreatment with $\mathrm{L} 1$ and V1 reduced the inflammatory cell migration during the peritonitis suggesting that these compounds can produce vascular changes directly on vascular smooth muscle cell or indirectly by means of a decrease of inflammatory mediators production during the topic inflammation induced by acetic acid, formalin or carrageenan, respectively, in the peritoneum or paw of mice.

Finally, we have shown that L1 and V1 produce a 
weak effect in the nitric oxide production on RAW 264.7 cells stimulated with LPS and did not affected the cell viability after the end of the experiments when evaluated by the MTT method.

We have shown in the present work, that $\mathrm{L} 1$, and in minor effect V1, administrated by intraperitoneal pathway, presents significant antinociceptive, anti-oedematogenic, anti-inflammatory effects and an additional weak inhibitory effect on nitric oxide production when tested on macrophage cell line (RAW 264.7).

In the present work, we have shown for the first time that synthetic $O$-prenyl derivatives L1 and V1 are effecttive on pain and inflammation in both in vitro and in vivo models. These results suggest that L1 and V1 can produce its antinociceptive and anti-inflammatory effects by means of an unclear pathway, but new assays are now being developed to confirm the hypothesis of modulation of inflammatory mediators such as bradykinin, prostanoids, and $\mathrm{NO}$, or neuronal modulation of nociceptive fibres.

\section{Acknowledgements}

The authors are grateful to the Bandeirante University of São Paulo, FAPESP (Research project: 2011/50435-8) for their financial support.

\section{REFERENCES}

[1] H. Süleyman, B. Demircan and Y. Karagöz, "Anti-Inflammatory and Side Effects of Cyclooxygenase Inhibitors," Pharmacological Reports, Vol. 59, No. 3, 2007, pp. 247-258.

[2] J. R. Vane and R. M. Botting, "Anti-Inflammatory Drugs and Their Mechanism of Action," Inflammation Research, Vol. 47, Suppl. 2, 1998, pp. S78-S87. doi:10.1007/s000110050284

[3] K. D. Rainsford, "Anti-Inflammatory Drugs in the 21st Century," Subcell Biochemistry, Vol. 42, 2007, pp. 3-27. doi:10.1007/1-4020-5688-5 1

[4] G. Appendino, S. Tagliapietra, G. Cravotto and M. Gian, "Structure and Synthesis of a Prenylated Acetophenone from Ferula communis L.," Gazzeta Chimica Italiana, Vol. 119, 1998, pp. 385-388.

[5] L. Pisco, M. Kordian, K. Peseke, H. Feist, D. Michalik, E. Estrada, J. Carvalho, G. Hamilton, D. Rando and J. Quincoces, "Synthesis of Compounds with Antiproliferative Activity as Analogues of Prenylated Natural Products Existing in Brazilian Propolis," European Journal of Medicinal Chemistry, Vol. 41, No. 3, 2006, pp. 401-407. doi:10.1016/j.ejmech.2005.10.020

[6] J. Quincoces Suárez, M. G. Jasiulionis, R. P. Santos, P. C. Pardi, D. G. Rando, M. R. Machado, C. Valduga and D. A. Maria, "Compostos Derivados de 4-Hidroxi-3metoxi-benzaldeído, Processo de Obtenção, Composição Farmacêutica, uso de um ou Mais Compostos," Brazilian Patent PI 0803375-7, 2008.
[7] M. C. Marcucci, F. Ferreres, C. García-Viguera, V. S. Bankova, S. L. De Castro, A. P. Dantas, P. H. Valente and N. Paulino, "Phenolic Compounds from Brazilian Propolis with Pharmacological Activities," Journal of Ethnopharmacology, Vol. 74, No. 2, 2001, pp. 105-112. doi:10.1016/S0378-8741(00)00326-3

[8] G. Appendino, E. Mercalli, N. Fuzzati, L. Arnoldi, M. Stavri, S. Gibbons, M. Ballero and A. Maxia, "Antimycobacterial Coumarins from the Sardinian Giant Fennel (Ferula communis)," Journal of Natural Products, Vol. 67, No. 12, 2004, pp. 2108-2110. doi:10.1021/np049706n

[9] E. Cunha, "Isolation of 3-[4-(3-Methyl-but-2-enyloxy)phenyl]-acrylic Acid Methyl Ester from Aerial Parts of Eriostemon auslalasius Pers. Subsp. Banksii," Australian Journal of Chemistry, Vol. 46, No. 10, 1993, pp. 15071514.

[10] N. Paulino, S. R. Abreu, Y. Uto, D. Koyama, H. Nagasawa, H. Hori, V. M. Dirsch, A. M. Vollmar, A. Scremin and W. Bretz, "Anti-Inflammatory Effects of a Bioavailable Compound, Artepillin C, in Brazilian Propolis," European Journal of Pharmacology, Vol. 587, No. 1-3, 2008, pp. 296-301. doi:10.1016/j.ejphar.2008.02.067

[11] M. Zimmermann, "Ethical Guidelines for Investigations of Experimental Pain in Conscious Animals," Pain, Vol. 16, 1983, pp. 109-110. doi:10.1016/0304-3959(83)90201-4

[12] R. O. de Campos, N. Paulino, C. H. da Silva, A. Scremin and J. B. Calixto, "Anti-Hyperalgesic Effect of an Ethanolic Extract of Propolis in Mice and Rats," Journal of Pharmacy and Pharmacology, Vol. 50, No. 10, 1998, pp. 1187-1193. doi:10.1111/j.2042-7158.1998.tb03333.x

[13] C. R. Corrêa and J. B. Calixto, "Evidence for Participation of B1 and B2 Kinin Receptors in formalin-Induced Nociceptive Response in the Mouse," British Journal of Pharmacology, Vol. 110, No. 1, 1993, pp. 193-198.

[14] N. B. Eddy and D. Leimbach, "Synthetic Analgesics. II. Dithienylbutenyl- and Dithienylbutylamines," The Journal of Pharmacology and Experimental Therapeutics, Vol. 107, No. 3, 1953, pp. 385-393.

[15] E. Wei, "Morphine Analgesia, Tolerance and Physical Dependence in the Adrenalectomized Rat," British Journal of Pharmacology, Vol. 47, No. 4, 1973, pp. 693-699.

[16] K. S. Tratsk, M. M. Campos, Z. R. Vaz, V. C. Filho, V. Schlemper, R. A. Yunes and J. B. Calixto, "Anti-Allergic Effects and Oedema Inhibition Caused by the Extract of Drymis winteri," Inflammation Research, Vol. 46, No. 12, 1997, pp. 509-514. doi:10.1007/s000110050234

[17] J. C. T. Carvalho, L. S. Santos, E. P. Viana, S. S. M. S. De Almeide, E. Marconato, M. Rodrigues, L. R. Ferreira and A. Van De Kamp, "Anti-Inflammatory and Analgesic Activities of the Crude Extracts from Stem Bark on Bauhinia guianensis," Pharmaceutical Biology, Vol. 37, 1999, pp. 281-284. doi:10.1076/phbi.37.4.281.5803

[18] V. N. Sumantran, "Cellular Chemosensitivity Assays: An Overview," Methods in Molecular Biology, Vol. 731, 2011, pp. 219-236. doi:10.1007/978-1-61779-080-5 19

[19] D. Sachs, F. Q. Cunha, S. Poole and S. H. Ferreira, "Tu- 
mour Necrosis Factor-Alpha, Interleukin-1beta and Interleukin-8 Induce Persistent Mechanical Nociceptor Hypersensitivity," Pain, Vol. 96, No. 1-2, 2002, pp. 89-97. doi:10.1016/S0304-3959(01)00433-X

[20] R. A. Ribeiro, M. L. Vale, S. M. Thomazzi, A. B. Paschoalato, S. Poole, S. H. Ferreira and F. Q. Cunha, "Involvement of Resident Macrophages and Mast Cells in the Writhing Nociceptive Response Induced by Zymosan and Acetic Acid in Mice," European Journal of Pharmacology, Vol. 387, No. 1, 2000, pp. 111-118. doi:10.1016/S0014-2999(99)00790-6

[21] C. J. Morris, "Carrageenan-Induced Paw Edema in the Rat and Mouse," Methods in Molecular Biology, Vol. 225, 2003, pp. 115-121.

[22] P. Crunkhorn and S. C. Meacock, "Mediators of the Inflammation Induced in the Rat Paw by Carrageenin," British Journal of Pharmacolology, Vol. 42, No. 3, 1971, pp. 392-402.

[23] C. Cayla, D. Labuz, H. Machelska, M. Bader, M. Schäfer and C. Stein, "Impaired Nociception and Peripheral Opioid Antinociception in Mice Lacking Both kinin B1 and B2 Receptors," Anesthesiology, Vol. 116, No. 2, 2012, pp. 448-457. doi:10.1097/ALN.0b013e318242b2ea

[24] M. Barth, M. Bondoux, J. M. Luccarini, V. Peyrou, P. Dodey, D. Pruneau, C. Massardier and J. L. Paquet, "From Bradykinin b2 Receptor Antagonists to Orally Active and Selective Bradykinin b1 Receptor Antagonists," Journal of Medicinal Chemistry, Vol. 55, No. 6, 2012, pp. 2574-2584. doi:10.1021/jm2016057

[25] S. P. Sardi, V. Rey-Ares, V. A. Pujol-Lereis, S. A. Serrano and R. P. Rothlin, "Further Pharmacological Evidence of Nuclear Factor-Kappa B Pathway Involvement in Bradykinin B1 Receptor-Sensitized Responses in Human Umbilical Vein," The Journal of Pharmacology and Experimental Therapeutics, Vol. 301, No. 3, 2002, pp. 975-980. doi:10.1124/jpet.301.3.975 